\title{
Câncer ambiental e ocupacional na América Latina
}

A América Latina é comumente desi gnada como a região geográfica compreendida ao sul da fronteira dos Estados Unidos com o M éxico. Do ponto de vista sociológico, entretanto, os latino-americanos constituem um imenso bloco com mais de quatrocentos milhões de pessoas compartilhando identidades comuns, e com compreensão mútua facilitada através de dois idiomas, o espanhol eo português. Neste sentido, a inserção da América Latina se exten de na realidade para latitudes mais setentrionais, como em Toronto e Montreal, para não mencionar as diversas grandes comunidades latinas nos Estados Unidos.

Historicamente, esta região passou por experiências comuns marcadas por uma conquista selvagem na qual sociedades nativas foram aniquiladas ou submetidas brutalmente ao domínio colonial. A escravidão indígena foi posteriormente ampliada com a introdução do tráfico de escravos da África, criando a base econômica sobre a qual floresceram as sociedades coloniais desde o século XVI. A partir da revolução industrial e de suas transformações introduzidas na região, modificaram-se as relações econômicas, mas não a situação de dependência em relação a outros centros no exterior. Assim, as economias latino-americanas têm historicamente se desenvolvido ao redor da exportação de insumos básicos, como cana-de-açúcar, café, cobre, borracha, estanho, frutas, carnes, couros, entre outros. Contudo, dificilmente, poder-se-ia dizer que esse processo tenha contribuído para um desenvolvimento social equilibrado nos países da América Latina.

Foi neste marco de referências, entretanto, que se forjaram as bases de desenvolvimento econômico e do trabalho na região. Durante o século XX, o processo de industrialização foi ampliado na América Latina, sobretudo no México, Argentina, Brasil, Chile e Venezuela, conduzindo à introdução de exposições ambi entais e ocupacionais a novos agentes, como o asbesto, pesticidas, cloreto de vinila e outros produtos químicos, radiações, tabagismo, entre outros.

Em conjunto, este novo padrão de exposições, além do processo de envelhecimento da população, tem provavelmente contribuído para uma modificação no perfil da distribuição do câncer nas populações latino-americanas. Assim, além da manutenção de taxas el evadas de incidência de câncer em localizações comumente observadas em outros países em desenvolvimento na África e na Ásia (como câncer de estômago, cérvico-uterino e da cavidade oral), as populações latino-ameri canas têm vivenciado um aumento recente na incidência de câncer de mama, cólon, pulmão e de próstata. Em acréscimo, o fenômeno de globalização econômica, facil itando a transferência de processos industriais danosos para os países em desenvolvimento, poderá vir a favorecer uma el evação da incidência de câncer nestas regi ões em futuro próximo.

A organização da Conferência Internacional sobre Câncer Ambiental e Ocupacional nos Países em Desenvolvimento, patrocinada pela Agência Internacional de Pesquisa em Câncer/Organização Mundial da Saúde, na Fundação Oswaldo Cruz, estimulou a estruturação deste suplemento dos Cadernos de Saúde Pública/Reports in Public Health. Sem pretensões de que este número especial se constitua numa análise abrangente da distribuição do câncer na América Latina, el e objetiva oferecer uma visão ampla valendo-se de contribui ções selecionadas de pesqui sadores que trabal ham nas áreas do câncer ambiental e ocupacional na região. Desta maneira, esperamos que este suplemento possa parcialmente contribuir com os objetivos almejados pela Conferência, ampliando a compreensão sobre alguns dos desafios presentes nos países em desenvolvimento para alcançar o controle do câncer ambiental e ocupacional.

\section{Sergio Koifman}

Departamento de Epidemiol ogia e Métodos Quantitativos em Saúde

Escola Nacional de Saúde Pública

Fundação Oswal do Cruz 


\section{Environmental and occupational cancer in Latin America}

Geographically, Latin America has been considered the region settled below the MexicanAmerican border. Nevertheless, from a sociological point-of-view, Latin-Americans constitute a huge block of more than 400 million people sharing common identities. They can quite easily understand each other towards two main languages (Spanish and Portuguese), having indeed organized large communities in such northern latitudes as in Toronto or Montreal, not to mention several large cities in United States.

Historically this region has also experienced quite common antecedents marked by a savage conquest in which native soci eties were either annihilated or brutally submitted to colonial domination. Native slavery was further enhanced by introducing slave trade from Africa, making the economic baseline in which colonial domain flourished since the sixteenth century. Following the Industrial Revolution and its repercussions in the region, economic relationships changed, but not economic dependance to other centers abroad. Therefore, Latin American economies have been historically involved with basic exports, such as sugar cane, coffee, copper, rubber, tobacco, fruits, meat, and others. As a whole, such endeavors barely contributed to a balanced social development in theses countries.

Nevertheless, this framework shaped the bases in which economic and labor developments were built in the region. In the 20th century, industrialization was enhanced in Latin America, mainly in some countries such as Mexico, Argentina, Brazil, Chile, Venezuela and others, yielding the introduction of occupational and environmental exposure to new chemical and physical agents.

As a whole, this new exposure pattern, besides population aging, probably has been contributing to a change in the epidemiological distribution of cancer in Latin American populations. Thus, besides the maintainance of high incidence rates of cancer in such sites commonly observed in other developing countries in Africa or Asia (such as stomach, uterine cervix and oral cavity cancer), Latin American populations have also been experiencing a recent increase in the incidence of breast, colon, lung and prostate cancer. Moreover, worldwide economic globalization has been creating conditions that favor the transfer of hazardous industries into developing countries, which could further contribute to a sharper increase of cancer incidence in these populations in the near future.

The organization from an International Conference on Environmental and Occupational Cancer in Developing Countries sponsored by the International Agency for Research on Cancer/WHO and carried out at Oswaldo Cruz Foundation, Ministry of Health of Brazil, stimulated interest in the development for this supplement of Cadernos de Saude Publi$\mathrm{ca/Reports} \mathrm{in} \mathrm{Public} \mathrm{Health.} \mathrm{Without} \mathrm{pretensions} \mathrm{to} \mathrm{be} \mathrm{a} \mathrm{comprehensive} \mathrm{analysis} \mathrm{of} \mathrm{cancer}$ distribution in Latin America, this special group aims to offer an overview of selected contributions from different researchers acting in the fields of environmental and occupational cancer in the region. Therefore, we hope this supplement could also contribute to accomplish some of the Conference targets, helping to improve understanding in the challenges presently facing devel oping countries towards envi ronmental and occupational cancer control. 